\title{
The Role of Institutional Investors in Corporate Governance of Their Portfolio Companies - The Case of Croatia
}

\author{
Ivana Đunđek Kokotec \\ Faculty of Organization and Informatics, University of Zagreb, \\ Croatia \\ idjundjek@foi.unizg.hr
}

\section{Silvije Orsag}

Faculty of Economics and Business, University of Zagreb, Croatia sorsag@efzg.hr

\section{Marina Klačmer Čalopa}

Faculty of Organization and Informatics, University of Zagreb,

Croatia

marina.klacmer@foi.unizg.hr

\author{
CroEconsur \\ Vol. 23 \\ No. 2 \\ December 2021 \\ pp. $105-129$
}

Received: March 23, 2021

Accepted: September 9, 2021

Research Article

doi:10.15179/ces.23.2.4

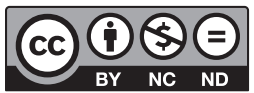

\section{Abstract}

The goal of this research is to examine the involvement of institutional investors in the corporate governance of companies in their portfolio by analyzing characteristics of institutional investors with respect to the type of investment, investment time horizon, and degree of involvement in the process of managing a company. The paper will outline the attitudes of managers on the level of investors' involvement in the governance process in order to identify determinants of investment decisions, decisions to take corrective actions to enhance corporate governance, or decisions to leave the ownership structure. A qualitative approach was chosen, consisting of a series of structural interviews with 25 fund managers of different types of institutional investors. The results indicate that institutional investors are involved in the corporate governance of their portfolio companies, 
and that control mechanisms they use include voting rights, direct communication with the management with the aim of discussing strategies for future development, and collaboration with other institutional investors in the ownership structure.

Keywords: institutional investors, corporate governance, control mechanisms, portfolio investment style, conceptual analysis

JEL classification: G18, G23, G32, G38, K22, M1

\section{Introduction}

Numerous previous studies support the view that institutional investors should be involved in the corporate governance of companies so as to protect their own investments and maintain the interest of their own investors by means of undertaking effective investments (Ingley \& van der Walt, 2004). This research is based on the thesis that institutional investors are involved in corporate governance. The goal of the research is to explain how their influence is manifested, whether it even exists, and whether their involvement in corporate governance differs with respect to investment time horizon and fund managers' portfolio investment style. As already indicated, the goal of corporate governance is to reduce the agency problem undermining business performance and effectiveness which is achieved by using various corporate governance control mechanisms. After having defined the general objective of the research, the main hypothesis was formulated:

H1: Institutional investors are involved in the corporate governance of companies in their portfolio.

\section{Literature Review}

Interest in this type of research was initiated by the growing importance of the role institutional investors have in corporate governance of companies primarily in developed countries, but the positive trend has also been identified in post- 
transition countries. Institutional investors became one of the most important participants in the capital market a couple of decades ago. Their importance stems from their contribution to the effectiveness of the whole financial system (Vittas, 1998; Davis \& Steil, 2002; Krišto, Stojanović, \& Pavković, 2014; Curkovic \& Kristo, 2017). Therefore, their role in the domain of corporate governance, where they perform a controlling function by supervising management, is necessary (Mehrani, Moradi, \& Eskandar, 2017). There is a need in contemporary jointstock companies, where there is a separation of ownership and management function, to increase shareholder value while limiting satisfaction and social ambitions of companies. Consequently, the system of corporate governance is of utmost value in this context as it provides companies with guidance for increasing their performance and enhancing their operating activities by reducing agency costs (Matić \& Papac, 2010; Orsag \& Sabol, 2014).

\subsection{Characteristics of Institutional Investors}

According to the investment time horizon, institutional investors can be grouped into two classes: passive investors and active investors. Institutional investors that have adopted an active management approach pursue investment and management strategies procuring returns that outperform the market, which is necessarily accompanied by higher management costs and transaction costs (Orsag, 2015). In contrast, passive institutional investors hold a diversified portfolio in order to make a profit by virtue of long-term economic, i.e. market, growth and development (Orsag, 2015). The results of previous research indicate that institutional investors maintain a long-time investment horizon with the aim of earning safe returns and allowing for a constant and slow increase in share prices. This is indicative of the passive style of portfolio management adopted by fund managers in institutional investor management companies (Nix \& Chen, 2013). Previous studies have shown that institutional investors prefer investing in large, established companies, which are perceived as safe investments offering higher expected returns (Agrawal \& Knoeber, 1996; Holland, 1998; Mallin, 1999; Tam 
$\&$ Tan, 2007). Accordingly, the objective institutional investors pursue by creating investment portfolios are consistent returns and annual dividend payments over a long investment horizon. Briefly, the aim of investment portfolios is to maximize shareholder wealth. In their research, McCahery, Sautner, and Starks (2016) confirm the argument that investors prefer long-term investment horizons, hence their interest in corporate governance.

Furthermore, Annuar (2015) indicates that institutional investors are inclined to favor conservative investment strategies as they promise steady returns on low-risk investments. The decision to invest in a particular company depends on a clearly defined company development strategy and an elaborate business plan which investors consider to be important indicators of future yields, in addition to the dividend policy. Additionally, particular importance is given to continual strategic assessments (Low \& Arumugam, 2001). In the case of long-term investments, institutional investors help to enhance corporate governance by means of their controlling function, which entails disciplining management so they act in the interest of shareholders (Attig, Cleary, El Ghoul, \& Guedhami, 2012) rather than their own interest, convergently reducing the information asymmetry and agency costs (Elyasiani \& Jia, 2008). Research conducted on this topic confirms that there is a difference in shareholders' investment styles, investment horizons, and involvement in corporate governance of companies. Therefore, the first auxiliary hypothesis serves to confirm that institutional investors prefer long-term investments in companies offering constant returns and slowly rising share prices.

H1.1.: Institutional investors prefer a long-term horizon of investing in liquid companies with clearly defined strategic developments, continuous and small increases in stock prices, dividend payments, and low investment risk.

\subsection{Corporate Governance Mechanisms}

In the context of corporate governance, there are several control mechanisms. The objective of them all is to increase shareholder wealth while limiting satisfaction 
and social goals of the company (Matić \& Papac, 2010; Orsag \& Sabol, 2014). Weir, Laing, and McKnight (2002) differentiate between internal (supervisory board structure, executive compensation, concentration of ownership, corporate reporting, relation with stakeholders) and external corporate governance mechanisms (market for corporate control, legislative and regulatory framework, competition circumstances, protection of minority shareholders) (Tipurić, 2006).

Annuar (2015) asserts that institutional investors' participation in corporate governance is highly important in that they control company management and maintain the value of their investment. Previous studies distinguish three mechanisms used by institutional investors in order to control the management. Mallin (1999) indicates that the most important mechanism is (1) the exercise of voting rights at the general assembly of shareholders, which grants an explicit power in management control to investors. Solomon (2007) contends that financial reporting is insufficient and specifies (2) a face-to-face communication with the management as the second control mechanism. Based on Holland (1998), Annuar (2015) indicates that the domain of communication refers to the meetings at which company strategies and management quality are discussed, which ultimately improves the efficacy of the corporate governance mechanisms. The third control mechanism refers to (3) cooperation with other institutional investors in the ownership structure of a company in order to create a representative group safeguarding their interests. Answers obtained in an interview conducted by Nix and Chen (2013) support all of these points by revealing that the most common methods institutional investors use to exercise their power include communication with the management, the exercise of voting rights, and cooperation with other shareholders. The second auxiliary hypothesis serves to investigate whether these three management control mechanisms are employed in the corporate governance of Croatian companies in their portfolio.

H1.2.: Active participation in the decision-making process is achieved through voting rights at the general assembly, communication with the management, and cooperation with other institutional investors present in the ownership structure. 
In addition to the mechanisms enabling institutional investors to engage in corporate governance, some barriers to their intervention in the management process have also been identified. One of the major challenges includes complex legislative frameworks imposing various investment restrictions on institutional investors, depriving them of the opportunity to take a more active role in the process of corporate governance (David \& Kochhar, 1996). The question arises as to what institutional investors can do if they are not content with the management of their portfolio company. The literature and previous research highlight two possible choices investors have when it comes to management control: the first one includes communication with management, i.e. the exercise of voting rights, whilst the second one refers to investors' decision to leave the company by selling shares ("voting with their feet") (Hirschman, 1970 cited in McCahery et al., 2016). As indicated above, institutional investors favor long-term investment horizons. Therefore, their threat to exit the ownership structure can be regarded as a disciplinary threat to management. Investors specify that they resort to this strategy only after having engaged in direct communication with management, which illustrates how these two mechanisms are complements rather than substitutes (McCahery et al., 2016). The role of the third auxiliary hypothesis is to test whether comprehensive regulations imposing investment restrictions on institutional investors are a major barrier to their active participation in corporate governance.

H1.3.: Comprehensive investment legislation limits the activities of institutional investors in the corporate governance of companies in their portfolio.

\subsection{Determinants of Institutional Investors' Engagement in Corporate Governance}

It has been established that institutional investors have a significant impact on corporate governance of portfolio companies, but it is also necessary to identify the various factors determining their ownership engagement in corporate governance. 
Previous studies indicate several determinants, such as institutional investors' objective, investment time horizon, investment strategy, portfolio structure, etc. Moreover, studies have shown that determinants may vary according to the type of institutional investor and within the same type. Institutional investors' engagement may range from a completely passive to a completely active management portfolio style (McNulty \& Nordberg, 2016).

By engaging in corporate governance, institutional investors perform not only their ethical, but also fiduciary duties. However, they also serve a far more important purpose by means of effective capital allocation and management control, thus directly fulfilling their primary function - maximization of shareholder wealth. The overall observation that shareholders strive to gain returns on the invested capital, therefore choosing to invest in transparent companies whose value is expected to increase in the long term, is consistent with the relevant theory. Shareholders, as much as institutional investors, are expected to continuously monitor the performance of a company in order to control the capital they invested themselves. If they duly fulfilled their primary function, shareholders would indirectly provide the whole market with necessary information, which would result in employment of new capital in particular companies, i.e. more effective allocation of capital employed at the moment.

Engagement in the corporate governance of a company requires institutional investors to be highly informed, which is to be ensured by the company. This information is used primarily in discussions of crucial business issues such as development strategies, dividend policy, etc. In this manner, institutional investors contribute to value added of companies, and help to enhance their financial position and performance. An in-depth analysis of theoretical premises helps to identify key determinants of institutional investors' engagement in corporate governance. They can be grouped into five classes: (1) type of institutional investor; (2) institutional investor's investment style; (3) investment time horizon; (4) investment purpose; (5) legislative restrictions (Maug, 1998; Ryan \& Schneider, 2002; Parrino, Sias, \& Starks, 2003; Al-Hawamdeh, 2004; Gaspar, 
Massa, \& Matos, 2005; Chen, Harford, \& Li, 2007; Cornett, Marcus, Saunders, \& Tehranian, 2007; Nix \& Chen, 2013; Çelik \& Isaksson, 2014; Annuar, 2015; McCahery et al., 2016; McNulty \& Nordberg, 2016; Mehrani et al., 2017).

\section{Methodology of Analysis}

Primary data in this research were used to examine the characteristics of institutional investors and identify the determinants that influence their decisions to invest in a particular company, take particular measures in the context of corporate governance, or leave a company. To this end, a structured interview was used as the research method ${ }^{1}$. It was conducted in direct communication with fund managers from different institutional investor management companies relevant for this research. The study population in this research includes investment funds, pension funds, and insurance companies with registered offices in the Republic of Croatia which hold stocks of Croatian companies listed on the Zagreb Stock Exchange in their portfolios. The balanced sample consists of investment funds, pension funds, and insurance companies which continuously operated between January 2010 and December 2019. In this study, institutional investors were examined both as a homogenous and heterogenous group (investment funds, pension funds, insurance companies). This eliminated the problem of inclusiveness occurring in previous studies, where authors examined institutional investors only as a homogenous group with shared goals and characteristics (Ashrafi \& Muhammad, 2014 cited in Fung \& Tsai, 2012). Finally, from the total of 31 investment companies, 25 participated in this research. Further analysis of responses will refer to 17 participants ( 9 investment funds, 4 pension funds, and 4 insurance companies). The rest of the insurance companies stated in their answers that they either do not invest in stocks of Croatian companies listed on the Zagreb Stock Exchange, as their investment strategy stipulates, or they do not invest significant amounts of money in stocks (the percentage of shares owned by them does not exceed 1 percent of the company's share capital). Therefore, they

1 The whole set of questions used in this research can be obtained on request from the authors. 
are not eligible to explain the impact they have on corporate governance in their respective portfolio companies.

The interview questions were grouped so as to form two sections: General information and Involvement in the process of corporate governance. The first section, General information, aims to identify investors' investment time horizon and portfolio investment style, and investigate whether the respondents are aware of the importance and ability of institutional investors to intervene in the corporate governance of their portfolio companies. The second section, Involvement in the process of corporate governance, aims to identify control mechanisms which institutional investors employ in their portfolio companies, as well as control mechanisms they use in response to their dissatisfaction with the corporate governance. Moreover, the purpose of this section is to identify stock selection criteria and reasons why institutional investors do not engage more actively in corporate governance.

In order to obtain the maximum possible number of responses, the survey was sent to the respondents by e-mail and post so they could either prepare for the face-to-face interview, or simply complete it and send it back by e-mail (Saunders, Lewis, \& Thornhill, 2009; Nix \& Chen, 2013). The survey was conducted in three iterations: the first iteration was conducted on December 13, 2019, the second iteration was repeated on January 31, 2020, and the third iteration was conducted on February 31, 2020. The entire research process ended on March 5, 2020. The length of the interviews varied between 30 and 60 minutes. Beforehand, the respondents were given a short introduction and were informed of the purpose, the whole process of the interview, and the fact that the interview was going to be recorded. They were asked to give permission to record them. The whole interview was recorded so that a transcript of the responses could be written later.

To examine the open-ended survey responses, content analysis was used to identify the occurrence of certain words or concepts in the text - a transcript of the openended survey responses. Berelson (1952) differentiates between several types of 
content analysis; specifically, in this research the conceptual analysis was used. The text had to be coded in categories by selectively reducing it to the words, groups of words, or phrases which were significant for the analysis. In this type of research, researchers do not use predetermined codes in the coding process. The goal of this analysis is to find answers to the initial questions. The text obtained in this manner was repeatedly reviewed in several iterations so that all key phrases, words, or segments of responses could be marked (Gaspar et al., 2005). However, other categories, i.e. unexpected concepts, especially those proposing new connections or explanations, were marked as well. Some new questions and responses, which originally were not predicted by the survey, were proposed at the end of the analysis. Glaser, Strauss, and Strutzel (1968) refer to this circular, iterative process of constantly comparing old and new data as grounded theory (White \& Marsh, 2006). Considering that the interview involved a relatively small sample, there was no need to use a software to conduct content analysis.

\section{Results and Discussion}

Based on the findings of this research, it can be concluded that institutional investors observed as a homogenous group prefer long-term investment horizons, seeing that the majority of the respondents stated that their average holding period is longer than five years. When asked to determine their portfolio investment style, a vast majority of the respondents described it as active management. If institutional investors are observed as a heterogenous group, it is evident that insurance companies have the longest time horizons, considering that all such respondents stated one year and longer as their average time horizon. Similarly, pension funds also stated that their average investment horizon is longer than one year. These findings are in accordance with theoretical expectations. According to the research conducted by Štimac, Orsag, and Dedi (2015) and Mehrani et al. (2017), pension funds and insurance companies are classified as active or longterm investors, which evidently have an impact on the performance of companies while applying stability and efficiency principles for investing. Investment funds 
seem to differ since the respondents from these companies mostly stated that, when it comes to stock investments, their average time horizon ranges between two and five years. Their investment style is more active than that of insurance companies and pension funds, which are both characterized by conservative and passive investment approaches with the goal of maximizing shareholder wealth, so short-term success is not of much importance to them in this respect.

Moreover, institutional investors contend that their interests are not so dissimilar from those of the management and other shareholders in the ownership structure. This is a consequence of the time horizon and divergent interests stemming from basic premises of the principal-agent relationship. The respondents emphasized the evident trend towards greater business transparency and management accountability leading to better corporate governance in the sense of making decisions that are in the interest of all shareholders. Furthermore, the respondents evaluated their supervisory control over the management as moderate.

Additionally, institutional investors maintain that their role in corporate governance is very beneficial for other shareholders as well since they protect the interests of minority shareholders. As for the cooperation and communication with other shareholders, it is clear that institutional investors communicate with other company shareholders, mostly with other investment funds, when there is a need. These results do not come as a surprise if institutional investors are observed as a homogenous group, given that the majority of the respondents work at investment fund management companies. From a heterogenous perspective, pension fund companies and insurance companies communicate with all types of shareholders (natural persons, legal entities, other pension funds or insurance companies), while investment funds mostly create synergies with other investment funds to solve issues. Direct communication with management is also considered important for the discussion of company performance. This communication usually takes place only when necessary rather than on a regular basis. Although the respondents stated that the communication between them and the management is improving, they regard it as a weakness which companies should strive to 
improve, and thus create greater business transparency and encourage direct or indirect communication. Consequently, the gap between ownership intentions and management interests would be reduced, leading to more profitable and safe management practices while the interests of all stakeholders would remain protected (Gillan \& Starks, 2003; Tipurić, 2006; Matić \& Papac, 2010; Dropulić Ružić, 2011; Orsag \& Sabol, 2014).

Moreover, the findings reveal that the mechanisms most intensively used by institutional investors as a homogenous group is the exercise of their voting rights at general assembly meetings, which grants an explicit power in the fundamentals of corporate governance control. The second most common control mechanism is direct communication with the management for the purpose of discussing strategies for the future development of the company. Another control mechanism appears to be cooperation with other institutional investors in the ownership structure of a company, whereby all parties make uncoordinated, but synergistic efforts to overcome challenges. According to this, the underlying premise of institutional investors' practices seems to be long-term focus, which protects their own investment, as well as the interests of all the other investors in a particular ownership structure. The conclusion remains the same even when the findings are analyzed from the point of view of each type of institutional investor observed as a heterogenous group. Additionally, it can be confirmed that these findings are in line with previous research results (Mallin, 1999; Ingley \& van der Walt, 2004; Solomon, 2007; Nix \& Chen, 2013; Annuar, 2015; McCahery et al., 2016).

According to previous research, there are two mechanisms which institutional investors most commonly resort to when they become dissatisfied with the corporate governance of a particular company. They primarily engage in communication with the management so that any corporate issues could be solved, while secondly, they threaten to sell the company's shares, what Hirschman refers to as "voice" or "exit" (Hirschman, 1970). However, these investors tend to make long-term investments, therefore this second mechanism is in a way a threat to the management to enhance the company's performance because 
exiting the ownership structure in an illiquid market is financially unprofitable for institutional investors (McCahery et al., 2016). These findings correspond to previous research results. If they assess that corporate governance in their portfolio companies is not satisfactory, institutional investors as a homogenous group will evidently strive to overcome any problems primarily by engaging in direct communication with the management. Secondly, they will exercise their voting rights at the general assembly of shareholders where they will object to certain business decisions and the direction the company might be heading. All of the mechanisms are considered to be compatible, which primarily give privilege to direct communication with management in order to enhance the company's performance while, naturally, reducing agency costs by directly influencing the management's decisions to optimally allocate the company's resources. When institutional investors are examined as a heterogenous group, the conclusion remains the same. All of the respondents stated that they intervene when they are not satisfied with the management, which indicates their active participation in the process of corporate governance of their portfolio companies.

The most common cause of non-participation in the corporate governance process is an insufficiently large share stake in the capital, which discourages investors from intervening in the governance process. The respondents also stated that a concentrated ownership structure of companies inhibits them from participating in corporate governance, which is directly connected with the outlined most common disincentive to shareholder activism. Moreover, another likely explanation for inactive behavior of institutional investors is related to the internal management of the examined investment funds, pension funds, and insurance companies. Respondents from these companies stated that the companies have a limited number of employees who could individually engage in the management processes of all the companies in their portfolios. The majority of the respondents do not agree with the statement that intervention in the corporate governance of companies is not part of their investment policies. Once again, this suggests that investors want and need to engage in the process of corporate governance 
of companies, which would secure the value of their investments. Disincentives to participate in corporate governance remain identical in the case of investment funds, regardless of whether institutional investors are examined as a homogenous or heterogenous group. In addition to a small share stake, insurance companies and especially pension funds stated legislative frameworks as another problem that does not allow their direct intervention in the corporate governance of companies.

The cases in which institutional investors would definitely intervene in the corporate governance process include unexpected changes in dividend payments, inadequate corporate governance, mergers and acquisitions, corporate fraud, and illicit block trading. A poor company development strategy and uncooperative management are also situations which require intervention in the process of corporate governance. As Low and Arumugam (2001) suggest in their conclusions, these situations are considered to be indications of future returns and dividends, which institutional investors find invaluable in the context of continual strategic assessments they undertake. The findings of this research are consistent with previous research results which indicate that institutional investors have a longterm positive impact on corporate governance by virtue of the control they have and exert by disciplining management to act in the best interest of shareholders rather than their own (Elyasiani \& Jia, 2008; Attig et al., 2012; Mehrani et al., 2017). Even when institutional investors are examined as a heterogenous group, their influence on the management of companies is equally evident, especially in the case of pension funds, which can be classified as active investors with a longterm focus (Štimac et al., 2015; Mehrani et al., 2017).

Institutional investors observed as a homogenous group primarily invest in companies with liquid stocks and clearly defined strategic development plans. Additionally, the results indicate that institutional investors prefer companies which are successful from the point of view of profitability (assets and capital) and sales growth. Consequently, these are usually large, established companies providing investors with steady returns, as research conducted by Agrawal and 
Knoeber (1996), Holland (1998), Mallin (1999), and Tam and Tan (2007) has already shown. McCahery et al. (2016) confirm the thesis that institutional investors prefer long-term time horizons and therefore show interest in corporate governance. This is also evident in the answers of our respondents who consider good corporate governance as a very important criterion when selecting companies to invest in. In their responses, they stated good corporate governance as the kind which is in compliance with the Corporate Governance Code. Regardless of whether institutional investors are examined as a homogenous or heterogeneous group, the results of the analysis remain unchanged. However, pension funds and insurance companies tend to stress dividend payment as an additional criterion. This is in line with the research conducted by Brown and Caylor (2004), in which they prove that good corporate governance, measured using executive and director compensation, is most often associated with good performance. Consequently, the underlying premise is that better-governed companies are more profitable, more valuable, and pay their shareholders higher dividends. In conclusion, the decision to invest in a particular company depends on a well-defined company development strategy and elaborate business plan, which investors consider to be important indicators of future earnings. Dividend policies emphasizing the importance of continually conducting strategic assessments are particularly emphasized, which is consistent with Low and Arumugam's (2001) research. Consequently, institutional investors prefer conservative investments which can provide them with stable returns at low risk levels, as Annuar's (2015) research has shown. Finally, the goal a particular institutional investor seeks to achieve by creating an investment portfolio includes an investment which can guarantee steady annual dividend yields and returns over a long investment horizon, i.e. shareholder wealth maximization.

When discussing corporate governance in general, the respondents raised some problems they face when they actually engage in the process of managing a company. Above all, these include complex legislative frameworks regarding investments, which restrict activities in the context of corporate governance of 
portfolio companies, i.e. prevent intervention in the governance process. This problem is evident in the case of pension funds, which are naturally subject to rigid legislative restrictions, given their purpose. Other investors state that the main impediments to their activism in the corporate governance process are uncooperative management and negligible holdings in the ownership structure, which preclude them the power needed to make major decisions. According to the respondents' statements, the management is not really interested in engaging in a dialogue with shareholders, who, nonetheless, believe that exactly communication with the management is crucial to protecting the interests of shareholders. Consequently, investors cannot utilize one of the more effective mechanisms of governance control - direct communication with management, which has the capacity to enhance company performance. Generally, the respondents stated that they had not faced any major barriers when they intervened in the corporate governance of companies in their portfolio.

In addition, institutional investors stated that the major challenge they face in the context of corporate governance is a lack of business transparency. This represents a serious problem because the backbone of good corporate governance is precisely business transparency, which protects the interests of all shareholders, especially minority shareholders. Furthermore, a recurring problem is the fact that the management is not really willing to cooperate with shareholders, hence the poor communication between them. This problem disincentivizes institutional investors from intervening in the process of corporate governance since they are deprived of one of the main mechanisms for controlling the management's actions - direct communication with the management. These problems are not restricted to particular investors or investor types, but rather are a more general phenomenon.

Based on the results, it can be concluded that auxiliary hypotheses H1.1. and H1.3. are accepted, whilst hypothesis H1.2. cannot be rejected. Deductively, the main hypothesis $\mathrm{H} 1$ of this paper is accepted since it has been proved that 
institutional investors are involved in the corporate governance of their portfolio companies.

\section{Limitations of the Study}

This research is based on the primary data obtained by the structured interview consisting of open-ended and closed-ended questions. An advantage of this research method is a two-way communication, whereby the respondent can counter-question the interviewer in case of uncertainties, or a new topic, which was not initially supposed to be discussed, can be started. Alongside the numerous benefits, there are many disadvantages of this research method as well. Specifically, potential problems may arise from questioning the validity and reliability of the obtained data, considering that the whole process is under human influence. Respondents' subjectivity and bias while answering the questions and the interviewer's familiarity with the topic and its interpretation may all compromise the objectivity of the research.

Moreover, the data analysis may cause additional problems since the reliability of conceptual analysis is based on the supposition that, in the coding process, the interviewer will consistently and incessantly choose the same data for a particular code and code them in the same manner over a period of time. Apart from reliability, it is equally important to ensure the validity of research data, which is achieved by identifying which categories may be responses to initial questions. The level of generalizability has the greatest impact on the validity of data obtained by the research. Here, the problem lies in the implicit concept analysis, which completely relies on the interviewer's subjective reflection. Consequently, the reproducibility of the analysis, and its subsequent conclusions and results, is inevitably limited. This is why it is necessary to develop precise coding rules which allow a third party to reproduce the data analysis. Reproducibility, or replicability, is crucial to the success of a conceptual analysis (Gottschalk, 2014; Patton, 2014; Krippendorff, 2018). Not only does the method limit the generalizability of the 
findings, but so does the relatively small sample size. Even though the response rate was fairly high (of 31 invited companies, 25 participated in the research), the sample size remains small, which is due to the fact that a relatively small number of the analyzed companies operate in the Croatian market. Furthermore, investment funds and pension funds may establish and manage one or more investment funds, which additionally limits the number of companies which are suitable to be part of this research sample.

\section{Conclusion}

Institutional investors intervene in the corporate governance process primarily by means of three fundamental control mechanisms: (1) the exercise of their voting rights at general assembly meetings, which grants them explicit power in the fundamentals of corporate governance control, (2) direct communication with the management in order to discuss strategies for the future development of the company, and (3) cooperation with other institutional investors in the ownership structure of the company, whereby all parties make uncoordinated, but synergistic efforts to solve issues. This illustrates the underlying principle of investors' practices - long-term investing, which protects both their investment and the interests of their shareholders.

The respondents in this research point out that their participation in the management process does not necessarily include direct influence in defining the business direction, i.e. business strategy. Instead, it entails getting timely, accurate, and complete information which allows them to monitor the future development of the company. Such a conclusion is partly in accordance with Holland's (1998) findings, which indicate that, in order to enhance the performance of the company, institutional investors most often discuss various segments of business rather than directly intervene in the governance process. The situations in which institutional investors take an active role in the process of corporate governance, especially pension funds, include unexpected changes in dividend payments, 
inadequate corporate governance, mergers or acquisitions, corporate fraud, and illicit block trading. Institutional investors consider these events as indications of future prospects such as earnings and dividends, which institutional investors find indispensable in the context of continual strategic assessments.

Overall, the findings are consistent with previous research which shows that institutional investors have a long-term positive impact on corporate governance by virtue of the control they have and exert by disciplining management to act in the best interest of all shareholders rather than their own (Elyasiani \& Jia, 2008; Attig et al., 2012; Mehrani et al., 2017).

As Nix and Chen (2013) indicate, communication between the management and institutional investors is an important control mechanism and a good starting point for the establishment of long-term relations. The advantages of direct communication between them are twofold. On the one hand, institutional investors have a better understanding of business models and development strategies of their portfolio companies. On the other hand, companies can express their achievements and prospective goals better in this manner, instead of communicating them by means of indirect instruments such as annual, semiannual, or quarterly reports. In any case, there is room for improvement. The respondents agree that business transparency and management cooperation in the sense of intensifying direct communication with investors should be improved, consequently reducing the gap between ownership intentions and management interests. The most important information institutional investors consider when making investment decisions refers to traditional information available from financial reports. This information primarily includes various financial indicators which reflect business performance and business security in terms of stock liquidity, debt structure, operating margin, and capital structure. However, it should be emphasized that there is a growing interest in information which is not exclusively available from financial reports, but rather from other various resources. To illustrate, this information refers to the corporate governance process as a whole, including environmental management and socially responsible 
business practices. Another type of information directly addressed to corporate governance policymakers and often publicly promoted by institutional investors is the importance of integrating modern standards in mandatory annual reports, e.g. new standards for non-financial reporting such as GRI Standards promoting global sustainability. Other information which institutional investors as a homogenous group tend to find highly important includes well-defined strategic development plans for the future, economic trends, i.e. trends within the business sector in which a particular company operates, etc.

The conclusion remains the same even when the findings are analyzed from the point of view of each type of institutional investor observed as a heterogenous group. As a result, greater profitability and business safety would be achieved and the interests of all stakeholders would be considered. As suggested by the literature, control mechanisms employed by institutional investors are considered compatible and complementary with the purpose of generating greater shareholder value while inevitably limiting satisfaction and social goals of companies (Matić \& Papac, 2010; Orsag \& Sabol, 2014; McCahery et al., 2016).

The recommendation for future research would be to extend research to other post-transition countries (in the region) in order to basically use a bigger sample and to be able to make a comparative analysis among them and with developed EU countries that have more liquid capital markets. 


\section{Literature}

Agrawal, A., \& Knoeber, C. (1996). Firm performance and mechanisms to control agency problems between managers and shareholders. Journal of Financial and Quantitative Analysis, 31(3), 377-397. doi: https://doi.org/10.2307/2331397

Al-Hawamdeh, A. (2004). Institutional investors and investment managers' involvement in corporate governance in the UK: Are they able and willing to hold corporate managers to account? (Doctoral dissertation). University of Leicester.

Annuar, H. A. (2015). Changes in ownership forms and role of institutional investors in governing public companies in Malaysia: A research note. Journal of Accounting \& Organizational Change, 11(4), 455-475.

doi: https://doi.org/10.1108/JAOC-08-2012-0068

Ashrafi, M., \& Muhammad, J. (2014). The new structure of corporate governance, institutional investors and capital structure: Evidence from Malaysia. European Online Journal of Natural and Social Sciences, 3(2), 298-314. Retrieved from: http://european-science.com/eojnss/article/view/698

Attig, N., Cleary, S., El Ghoul, S., \& Guedhami, O. (2012). Institutional investment horizon and investment-cash flow sensitivity. Journal of Banking \& Finance, 36(4), 1164-1180. doi: https://doi.org/10.1016/j.jbankfin.2011.11.015

Berelson, B. (1952). Content analysis in communication research. Glencoe, IL: The Free Press.

Brown, L. D., \& Caylor, M. L. (2004). Corporate governance and firm performance. Georgia State University Working Paper.

doi: http://doi.org/10.2139/ssrn.586423

Çelik, S., \& Isaksson, M. (2014). Institutional investors and ownership engagement. OECD Journal: Financial Market Trends, 2013(2), 93-114. doi: https://doi.org/10.1787/fmt-2013-5jz734pwtrkc

Chen, X., Harford, J., \& Li, K. (2007). Monitoring: Which institutions matter? Journal of Financial Economics, 86(2), 279-305.

doi: https://doi.org/10.1016/j.jfineco.2006.09.005 
Cornett, M. M., Marcus, A. J., Saunders, A., \& Tehranian, H. (2007). The impact of institutional ownership on corporate operating performance. Journal of Banking \& Finance, 31(6), 1771-1794.

doi: https://doi.org/10.1016/j.jbankfin.2006.08.006

Curkovic, M., \& Kristo, J. (2017). Performance measurement of UCITS investment funds in Croatia. UTMS Journal of Economics, 8(1), 11-18. Retrieved from: http://hdl.handle.net/10419/174162

David, P., \& Kochhar, R. (1996). Barriers to effective corporate governance by institutional investors: Implications for theory and practice. European Management Journal, 14(5), 457-466. doi: https://doi.org/10.1016/0263-2373(96)00039-4

Davis, E. P., \& Steil, B. (2002). Institutional investors. London: The MIT Press.

Dropulić Ružić, M. (2011). Korporativno upravljanje u hotelskim poduzećima - slučaj Hrvatske. Ekonomska misao i praksa, 20(1), 171-201. Retrieved from: https://hrcak.srce.hr/69710

Elyasiani, E., \& Jia, J. J. (2008). Institutional ownership stability and BHC performance. Journal of Banking \& Finance, 32(9), 1767-1781. doi: https://doi.org/10.1016/j.jbankfin.2007.12.010

Fung, S., \& Tsai, S. C. (2012). Institutional ownership and corporate investment performance. Canadian Journal of Administrative Sciences/Revue Canadienne des Sciences de l'Administration, 29(4), 348-365.

doi: https://doi.org/10.1002/cjas.1232

Gaspar, J. M., Massa, M., \& Matos, P. (2005). Shareholder investment horizons and the market for corporate control. Journal of Financial Economics, 76(1), 135165. doi: https://doi.org/10.1016/j.jfineco.2004.10.002

Gillan, S., \& Starks, L. T. (2003). Corporate governance, corporate ownership, and the role of institutional investors: A global perspective. Journal of Applied Finance, 13(2). Retrieved from: https://papers.ssrn.com/sol3/papers.cfm?abstract_id=480983 
Glaser, B. G., Strauss, A. L., \& Strutzel, E. (1968). The discovery of grounded theory: Strategies for qualitative research. Nursing Research, 17(4), 364. Retrieved from: https://journals.lww.com/nursingresearchonline/Citation/1968/07000/The_ Discovery_of_Grounded_Theory_Strategies_for.14.aspx

Gottschalk, L. A. (2014). Content analysis of verbal behavior: New findings and clinical applications. London and New York, NY: Routledge, Taylor \& Francis Group.

Hirschman, A. O. (1970). Exit, voice, and loyalty: Responses to decline in firms, organizations, and states. Cambridge, MA: Harvard University Press.

Holland, J. (1998). Influence and intervention by financial institutions in their investee companies. Corporate Governance: An International Review, 6(4), 249264. doi: https://doi.org/10.1111/1467-8683.00113

Ingley, C. B., \& van der Walt, N. T. (2004). Corporate governance, institutional investors and conflicts of interest. Corporate Governance: An international Review, 12(4), 534-551. doi: https://doi.org/10.1111/j.1467-8683.2004.00392.x

Krippendorff, K. (2018). Content analysis: An introduction to its methodology. Thousand Oaks, CA: Sage Publications.

Krišto, J., Stojanović, A., \& Pavković, A. (2014). Impact of institutional investors on financial market stability: Lessons from financial crisis. International Journal of Diplomacy and Economy, 2(1-2), 102-117. doi: https://doi.org/10.1504/IJDIPE.2014.060746

Low, K. L. T., \& Arumugam, S. (2001). The sustainability of business corporate governance: Evidence from the Malaysia public-listed companies. British Accounting Association Special Interest Group on Corporate Governance. doi: https://doi.org/10.2139/ssrn.294577

Mallin, C. (1999). Financial institutions and their relations with corporate boards. Corporate Governance: An International Review, 7(3), 248-255. doi: https://doi.org/10.1111/1467-8683.00156 
Matić, B., \& Papac, N. (2010). Characteristics of the corporate bank governance system in Bosnia and Herzegovina. Ekonomski vjesnik/Econviews: Review of Contemporary Business, Entrepreneurship and Economic Issues, 23(1), 80-92. Retrieved from: https://hrcak.srce.hr/file/87592

Maug, E. (1998). Large shareholders as monitors: Is there a trade-off between liquidity and control? The Journal of Finance, 53(1), 65-98.

doi: https://doi.org/10.1111/0022-1082.35053

McCahery, J. A., Sautner, Z., \& Starks, L. T. (2016). Behind the scenes: The corporate governance preferences of institutional investors. The Journal of Finance, 71(6), 2905-2932. doi: https://doi.org/10.1111/jofi.12393

McNulty, T., \& Nordberg, D. (2016). Ownership, activism and engagement: Institutional investors as active owners. Corporate Governance: An International Review, 24(3), 346-358. doi: https://doi.org/10.1111/corg.12143

Mehrani, S., Moradi, M., \& Eskandar, H. (2017). Institutional ownership type and earnings quality: Evidence from Iran. Emerging Markets Finance and Trade, 53(1), 54-73. doi: https://doi.org/10.1080/1540496X.2016.1145114

Nix, P., \& Chen, J. (2013). The role of institutional investors in corporate governance: An empirical study. London: Palgrave Macmillan.

doi: https://doi.org/10.1057/9781137327031

Orsag, S. (2015). Investicijska analiza. Zagreb: Avantis.

Orsag, S., \& Sabol, A. (2014). Risk management and corporate governance: Through the looking glass. In D. Miloš Sprčić (Ed.), Risk management: Strategies for economic development and challenges in the financial system (pp. 29-49). New York, NY: Nova Science Publishers.

Parrino, R., Sias, R. W., \& Starks, L. T. (2003). Voting with their feet: Institutional ownership changes around forced CEO turnover. Journal of Financial Economics, 68(1), 3-46. doi: https://doi.org/10.1016/S0304-405X(02)00247-7

Patton, M. Q. (2014). Qualitative research \& evaluation methods: Integrating theory and practice. Thousand Oaks, CA: Sage Publications. 
Ryan, L. V., \& Schneider, M. (2002). The antecedents of institutional investor activism. Academy of Management Review, 27(4), 554-573.

doi: https://doi.org/10.5465/amr.2002.7566068

Saunders, M., Lewis, P., \& Thornhill, A. (2009). Research methods for business students. London: Pearson Education.

Solomon, J. (2007). Corporate governance and accountability. Hoboken, NJ: John Wiley \& Sons.

Štimac, D., Orsag, S., \& Dedi, L. (2015). Efficiency of different pension fund investment regulation models. In J. Bell (Ed.), Proceedings of the Forty-Fourth Annual Meeting of the Western Decision Sciences Institute.

Tam, O. K., \& Tan, M. G. S. (2007). Ownership, governance and firm performance in Malaysia. Corporate Governance: An International Review, 15(2), 208-222. doi: https://doi.org/10.1111/j.1467-8683.2007.00555.x

Tipurić, D. (2006). Nadzorni odbor i korporativno upravljanje. Zagreb: Sinergijanakladništvo.

Vittas, D. (1998, June). Institutional investors and securities markets: Which comes first? The World Bank Development Research Group. Paper presented at the Annual Bank Conference on Development Economics, Latin America and the Caribbean, San Salvador.

Weir, C., Laing, D., \& McKnight, P. J. (2002). Internal and external governance mechanisms: Their impact on the performance of large UK public companies. Journal of Business Finance \& Accounting, 29(5-6), 579-611. doi: https://doi.org/10.1111/1468-5957.00444

White, M. D., \& Marsh, E. E. (2006). Content analysis: A flexible methodology. Library Trends, 55(1), 22-45. doi: https://doi.org/10.1353/lib.2006.0053 